\title{
The Use of V.A.C. VERAFLO CLEANSE CHOICE in the Burn Population
}

\author{
Marc R. Matthews ${ }^{1}$, Aaron Hechtman ${ }^{1}$, Asia N. Quan ${ }^{2}$, Kevin N. Foster ${ }^{1}$, Luis G. Fernandez ${ }^{3}$ \\ 1. Surgery, Arizona Burn Center, Phoenix, USA 2. Pharmacy, Maricopa Integrated Health System, Phoenix, USA 3. \\ Surgery, University of North Texas Health Science Center, Fort Worth, USA
}

Corresponding author: Marc R. Matthews, marc_matthews@dmgaz.org

\begin{abstract}
Negative pressure wound therapy (NPWT) is routinely used in the treatment of acute and chronic wounds. The technology continues to evolve with improved results NPWT is routinely used at the Arizona Burn Center and the addition of the V.A.C. VERAFLO CLEANSE CHOICE ${ }^{\mathrm{TM}}$ with its reticulated open foam device has been used with promising results in a variety of complicated wounds. We present a case series involving the use of this negative pressure wound therapy device and irrigation in burn and necrotizing soft tissue patients treated at the Arizona Burn Center.
\end{abstract}

Categories: General Surgery

Keywords: burn, cleanse choice, hypochlorous acid

\section{Introduction}

Contact burns are very prevalent during the Arizona summer [1]. Negative pressure wound therapy (NPWT) has been effective in the treatment of acute and chronic wounds. NPWT is routinely used to assist in the formation of granulation tissue, increase in wound blood flow, removal of bacteria and its fibrinous exudate, wound edema, and subsequent wound closure [2]. Advances in this technology have allowed for improved results utilizing new devices, such as V.A.C. VERAFLO CLEANSE CHOICE ${ }^{\mathrm{TM}}$ (VVCC, KCI, Acelity, San Antonio, TX, US). VVCC is a reticulated open cell foam dressing (ROCF) that allows for the instillation of an irrigant in order to lavage the wound bed with the removal of the thickened wound exudate and prokaryotic materials. The VVCC also helps large and complex acute and chronic wounds not only remove fibrinous and bacterial exudate but also increases granulation tissue [3-4]. The use of instillation therapy with various irrigants (normal saline, prontosan, and hypochlorous ( $\mathrm{HOCl}$ ) acid) have also been described in combination with NPWT and ROCF dressings [3-5]. Such new adjuncts have helped with a more rapid tissue defect contraction, bacterial exudate clearance, and subsequent skin closure with skin grafting techniques. The addition of Vashe ${ }^{\circledR}$ (Stead Med, Inc, Fort Worth, TX, US) (HOCl) instillation therapy provides an effective medium to assist in a neutrophil respiratory burst in the killing of bacteria thereby eliminating any prokaryotic organisms within 15 seconds of contact. At the Arizona Burn Center, we routinely use VVCC for

Received 09/21/2018

Review began 10/15/2018 Review ended 11/14/2018 Published 11/26/2018

\section{() Copyright 2018}

Matthews et al. This is an open access article distributed under the terms of the Creative Commons Attribution License CC-BY 3.0., which permits unrestricted use, distribution, and reproduction in any medium, provided the original author and source are credited. large soft tissue defects following deep skin tangential excisions or soft tissue debridements whether from burns or necrotizing soft tissue infections. Typically, requiring multiple NPWT changes over weeks to allow for defect closure prior to skin grafting, VVCC has been trialed at our burn center with encouraging results. The purpose of this case series is to review the use and promising results of VVCC and HOCl irrigation in the treatment of a variety of complicated wounds at our burn center.

\section{Case Presentation}

\section{Case 1: contact burn to left hip}

A 77-year-old male was admitted for contact burns to the bilateral lower extremities and over the left hip, involving not only the skin but a burn injury down to the fascia and muscle. The patient had multiple medical comorbidities, including diabetes mellitus and hyperlipidemia. After debridement and dressing changes (Figure 1), attempts at grafting the site with split-thickness skin grafts (meshed 2:1, $150 \mathrm{sq} \mathrm{cm}$ ) resulted in graft loss within days, secondary to an inadequate depth of debridement and the lack of appropriate granulation tissue presence. Therefore, the patient was transitioned into VVCC NPWT to assist in irrigation debridement, granulation tissue formation, and wound contraction with the addition of Vashe ${ }^{\circledR}$ instillation at $30 \mathrm{ml}$ for 20 minutes duration every three hours before returning to suction for over two weeks. NPWT suction was maintained at $125 \mathrm{mmHg}$ while on suction. Rapid improvement in wound granulation tissue formation was noted ("comedones" or discrete and increased granulation tissue within the ROCF hole boundaries, Figure 2). The patient continues to follow up in our clinic with planned skin grafting at the time of this manuscript's submission. 


\section{Cureus}

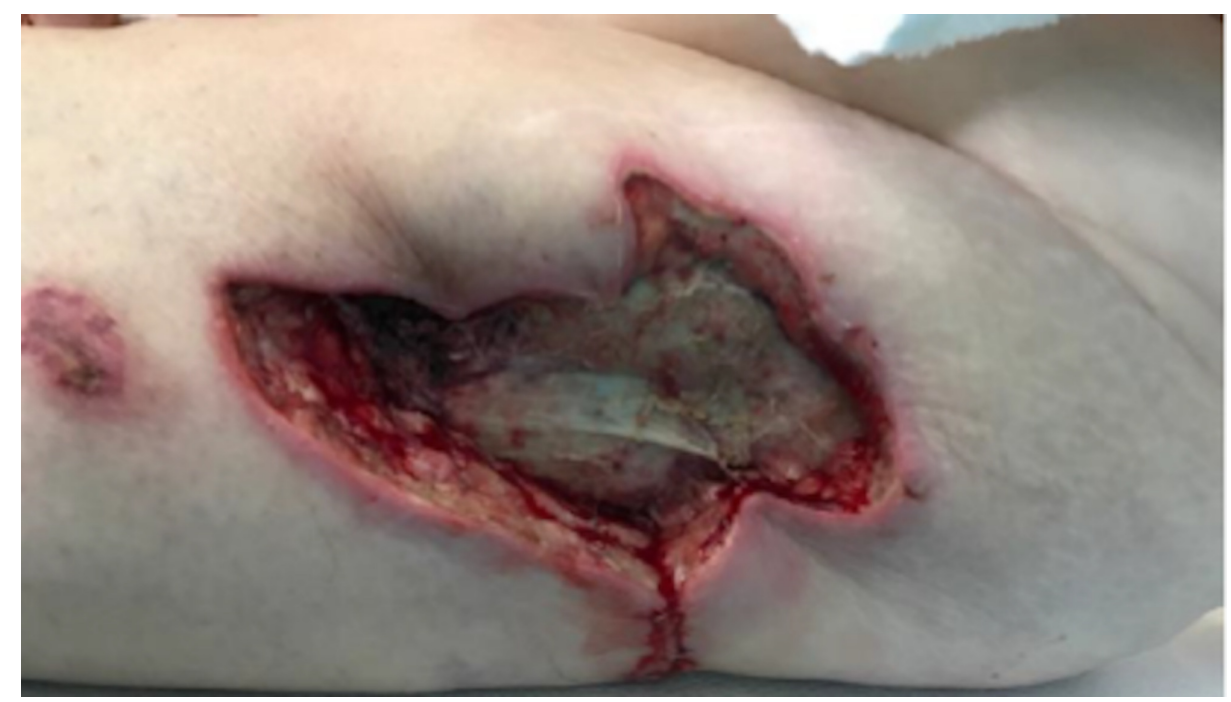

FIGURE 1: Initial debridement of burn eschar revealing deep necrotic tissue still in place

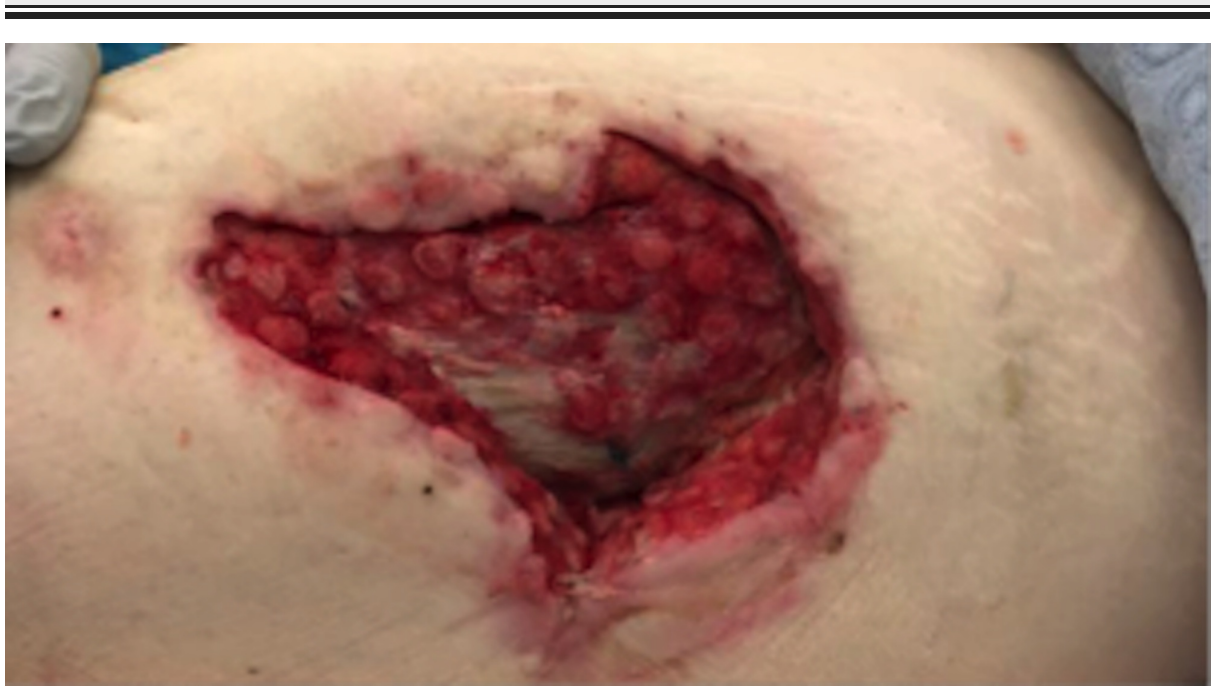

FIGURE 2: Rapid improvement in wound granulation tissue showing classic VVCC "comedone" development with increased granulation tissue within the ROCF hole boundaries

VVCC: V.A.C. VERAFLO CLEANSE CHOICETM; ROCF: reticulated open cell foam dressing

\section{Case 2: contact burn to left buttock}

An 87-year-old male was admitted for contact burns following a syncopal episode. The wounds were ful thickness burns requiring excision down to the subcutaneous tissue (Figure 3). A significant soft tissue defect over the left buttock was noted and VVCC NPWT was placed over the wound. Vashe instillation was started at $30 \mathrm{ml}$ for 20 minutes every three hours before returning to NPWT suction at $125 \mathrm{mmHg}$, which was applied to assist in the debridement and granulation of the wound. Short-term therapy with the VVCC resulted in a healthy granulation bed demonstrating near-skin-level comedone granulation tissue formation (Figure 4). The patient received an autologous skin graft (meshed 1:1, $200 \mathrm{sq} \mathrm{cm}$ ) after the completion of VVCC therapy with $100 \%$ skin graft take (Figure 5). 


\section{Cureus}

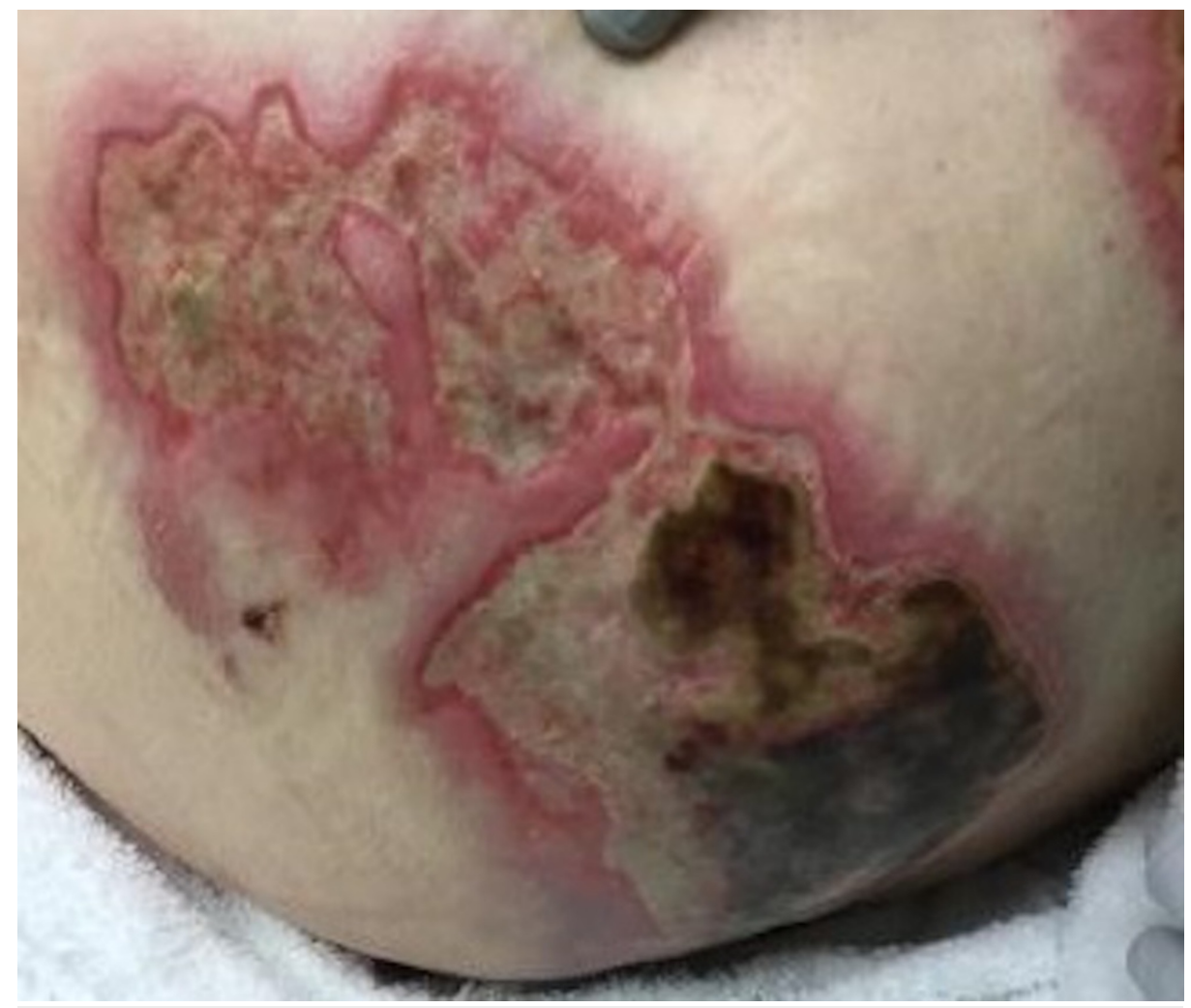

FIGURE 3: Initial third-degree burn wounds to the patient's left buttocks and hip 


\section{Cureus}

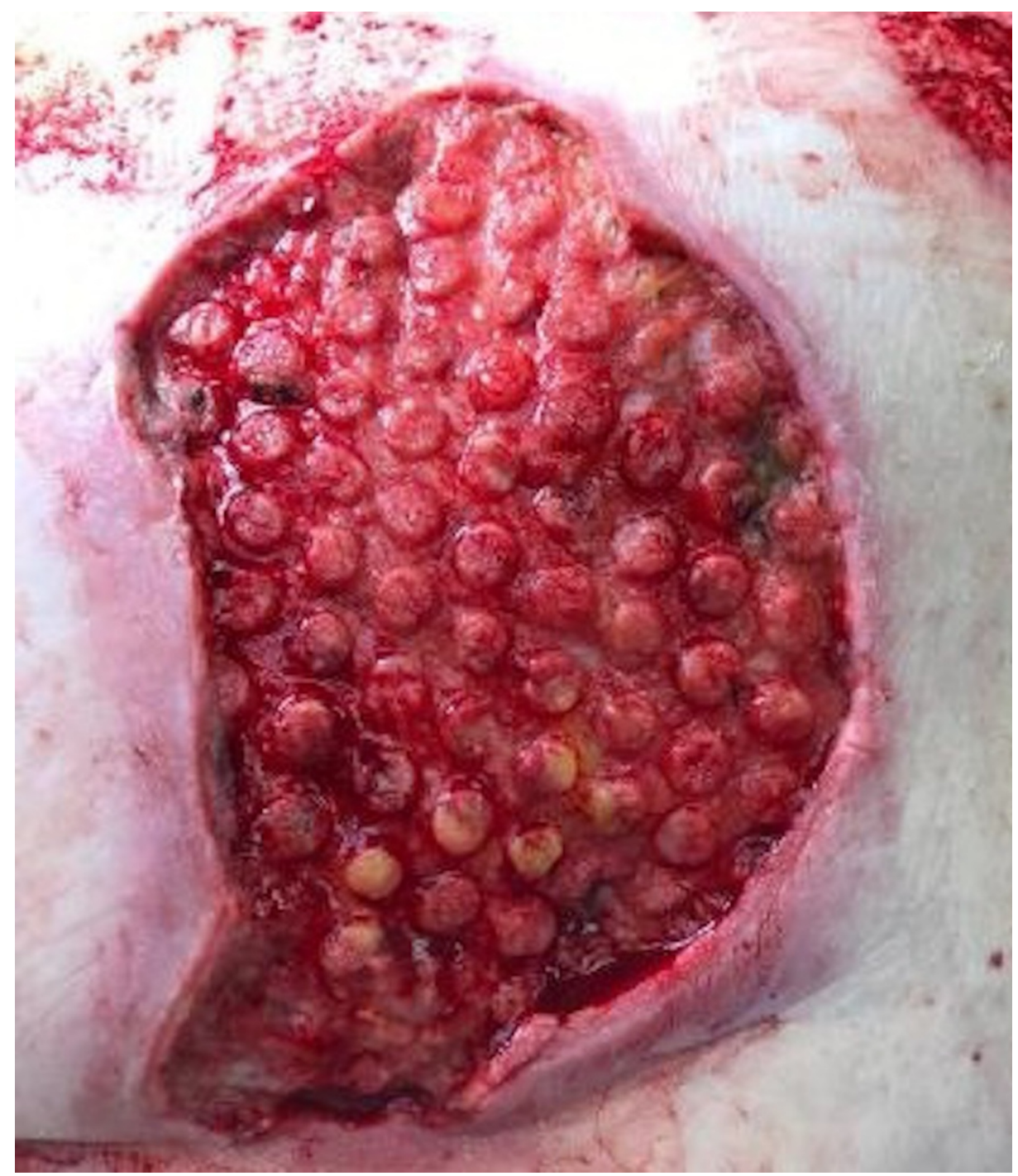

FIGURE 4: Rapid improvement in wound granulation tissue after several days post-excision showing classic VVCC "comedone" development with increased granulation tissue within the ROCF hole boundaries VVCC: V.A.C. VERAFLO CLEANSE CHOICE ${ }^{\mathrm{TM}}$; ROCF: reticulated open cell foam dressing 


\section{Cureus}

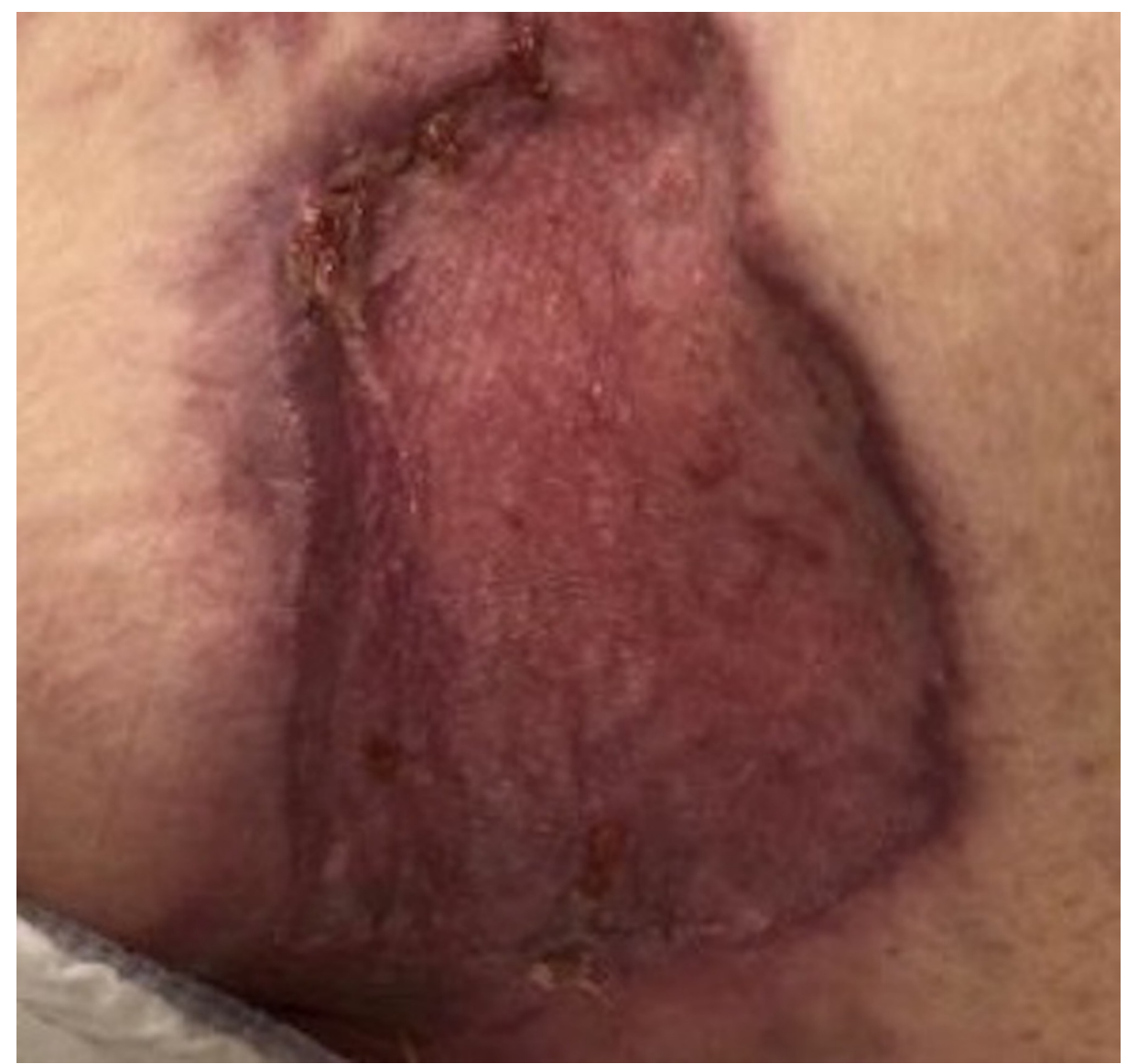

FIGURE 5: Closure of left buttock and hip wounds after standard splitthickness skin grafting techniques

\section{Case 3: contact burns to bilateral buttocks}

A 61-year-old female was admitted with full thickness contact burns to the bilateral buttocks (Figure 6). Initially, this was debrided down to the soft tissues. After a week of dressing changes, an autologous skin graft was applied (meshed 1:1, $100 \mathrm{sq} \mathrm{cm}$ ) but the skin graft failed and necessitated a return to the operating room for further debridement. A VVCC NPWT was placed with improved granulation tissue formation (Figure 7). Vashe solution was used to irrigate the wound with $30 \mathrm{ml}$ for a 20 minute dwell time every three hours with a NPWT suction of $125 \mathrm{mmHg}$. Eventual split-thickness skin grafting to the bilateral buttocks had a $100 \%$ graft take (Figure 8 ).

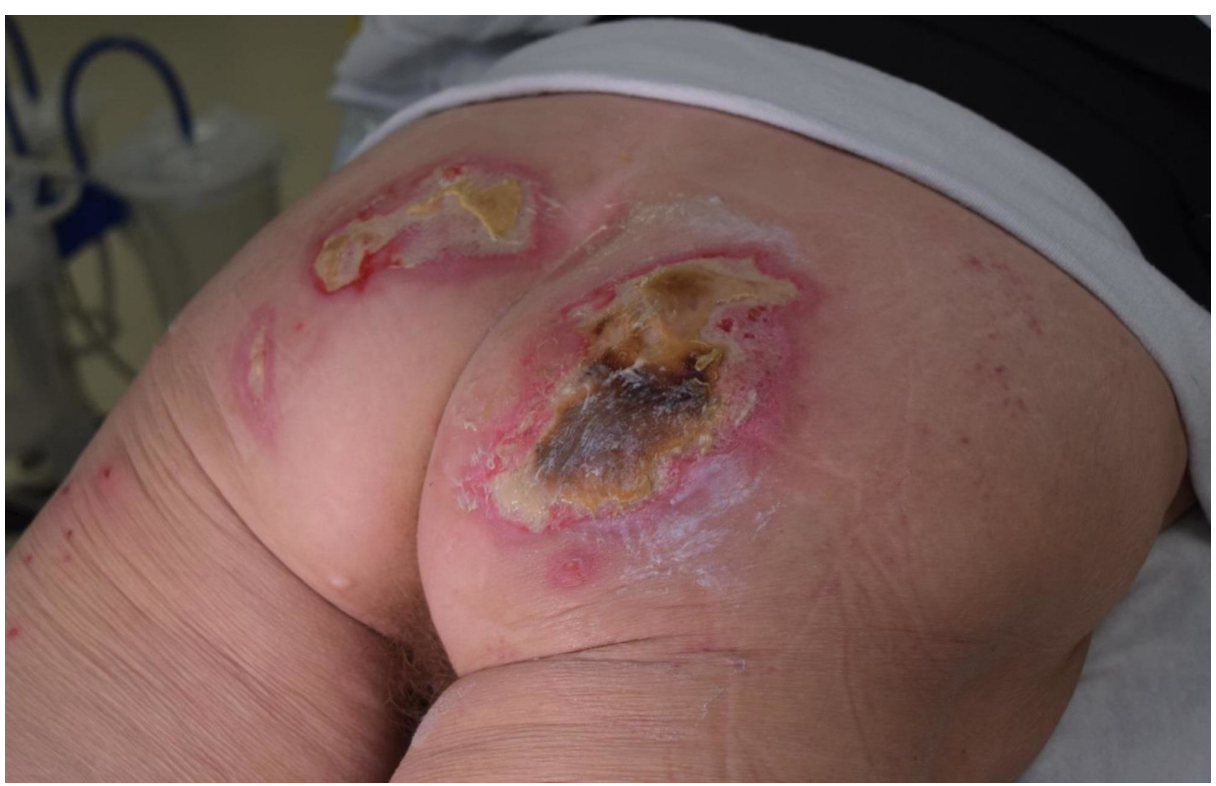




\section{Cureus}

FIGURE 6: Initial bilateral buttock contact burn wounds

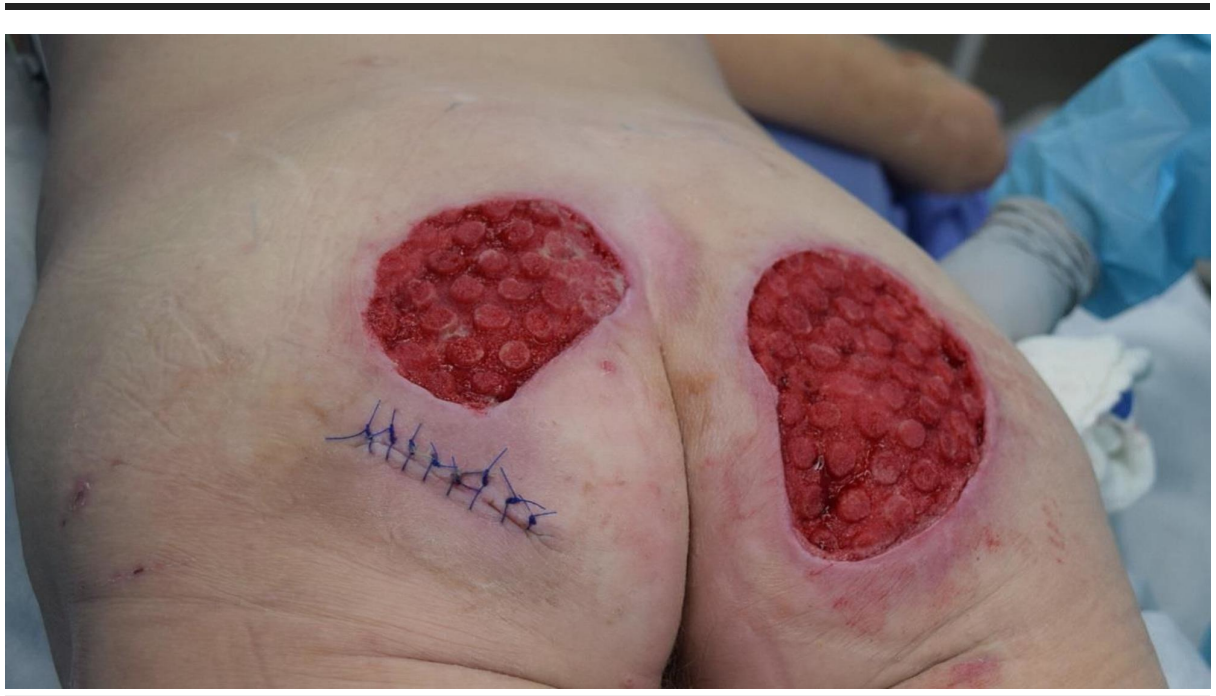

FIGURE 7: Afterburn wound eschar debridement and several days of VVCC, appearance of the classic VVCC "comedone" development with increased granulation tissue within the ROCF hole boundaries

VVCC: V.A.C. VERAFLO CLEANSE CHOICETM; ROCF: reticulated open cell foam dressing

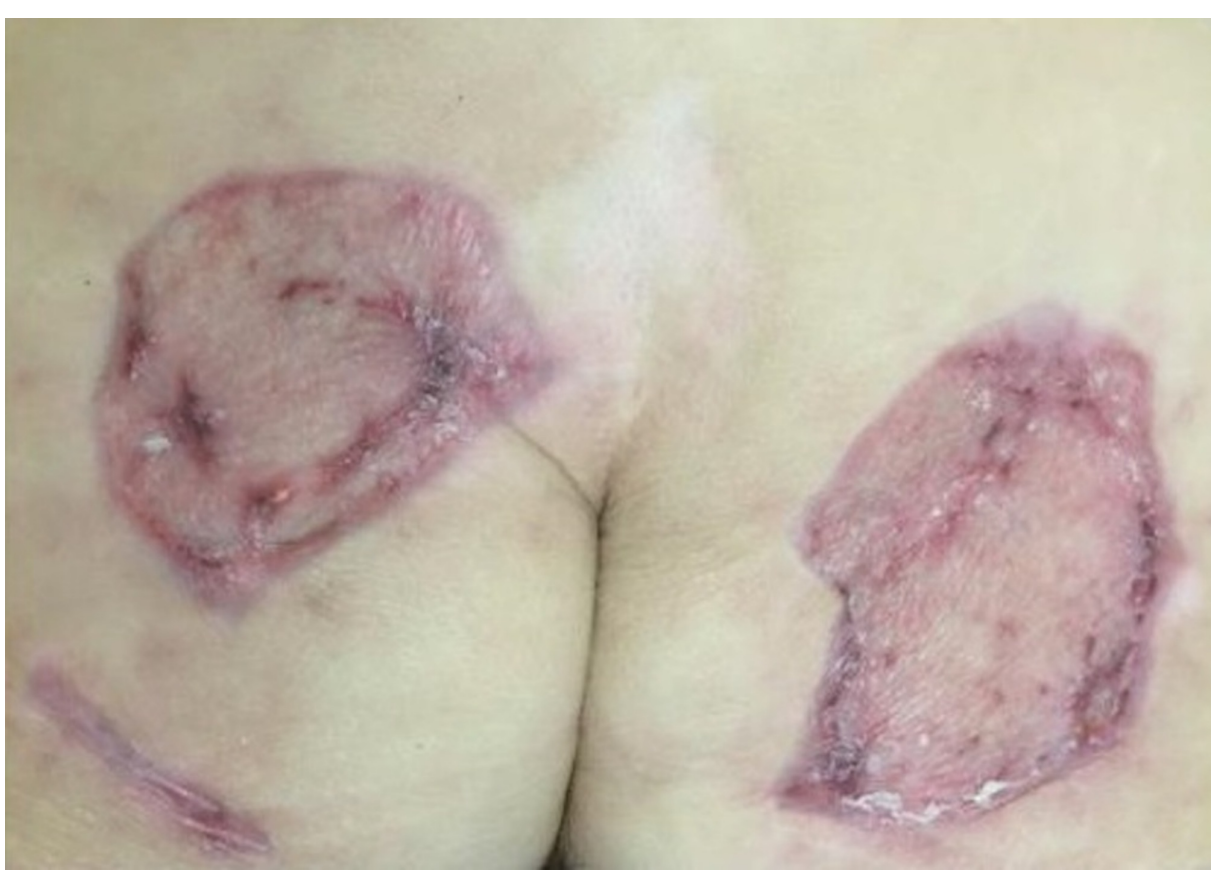

FIGURE 8: Closure of the bilateral buttock wounds after standard splitthickness skin grafting techniques

\section{Case 4: contact burns to the anterior torso and bilateral lower} extremities

A 76 -year-old male admitted with $21 \%$ total body surface area (TBSA) full thickness contact burns to his anterior torso and bilateral lower extremities following a ground level fall. The patient was debrided multiple times, which included a right, above-knee amputation, and autologous skin grafting to the anterior upper torso and right thigh. Deeper tissue defects of the lower abdomen (Figure 9) and left lower extremity (Figure 


\section{Cureus}

10) required the placement of the VVCC NPWT system with $\mathrm{HOCl}$ instillation of approximately $30 \mathrm{ml}$ to the lower abdomen and $30 \mathrm{ml}$ to the left lower extremity for 30 minutes every three hours with an NPWT suction of $125 \mathrm{mmHg}$. After two weeks of therapy (Figures 11-12), the patient had an autologous skin graft applied to the anterior torso and left lower extremity (meshed 2:1, $1400 \mathrm{sq} \mathrm{cm}$ ). There was a 100\% skin graft take to the lower abdominal torso and 90\% skin graft take of the left lower extremity (Figures 13-14).

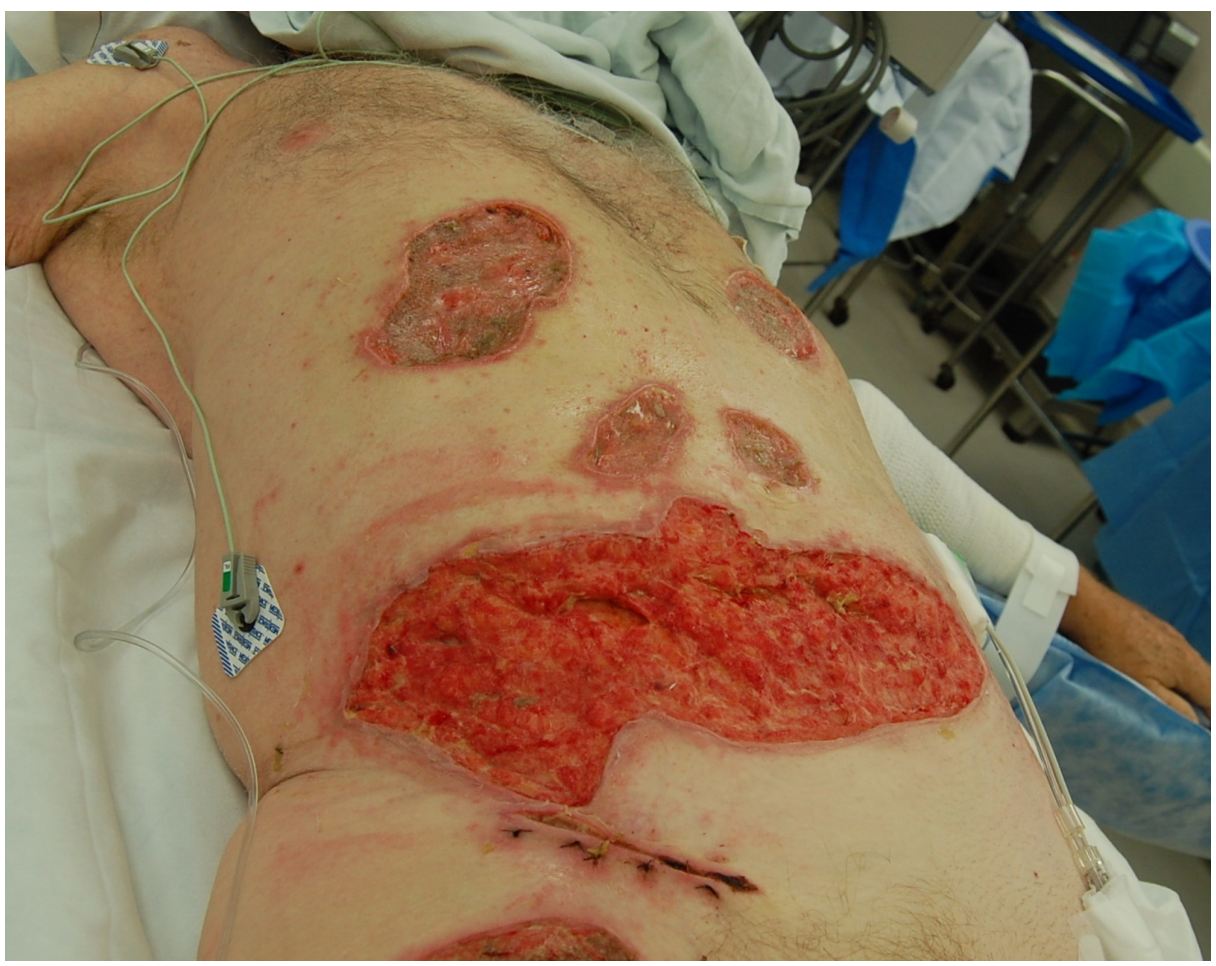

FIGURE 9: Initial debridement of an abdominal burn eschar

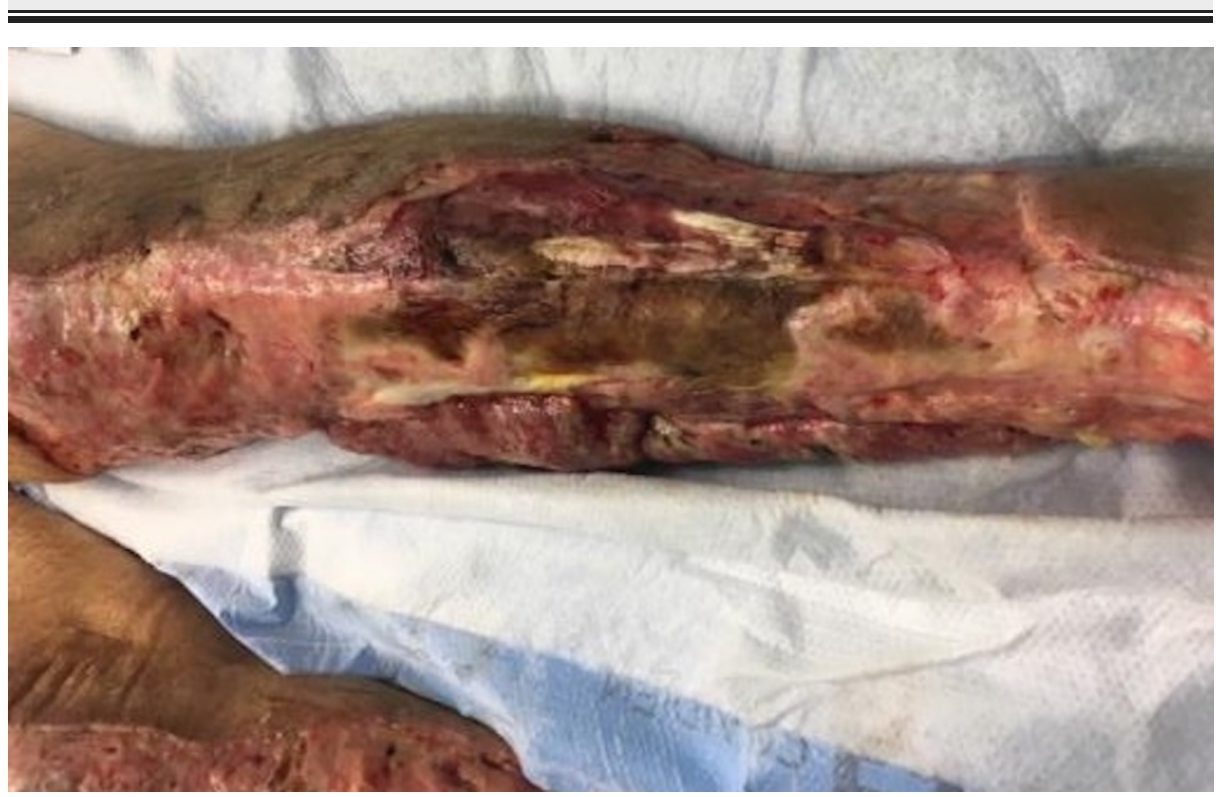

FIGURE 10: Initial left leg burn eschar 


\section{Cureus}

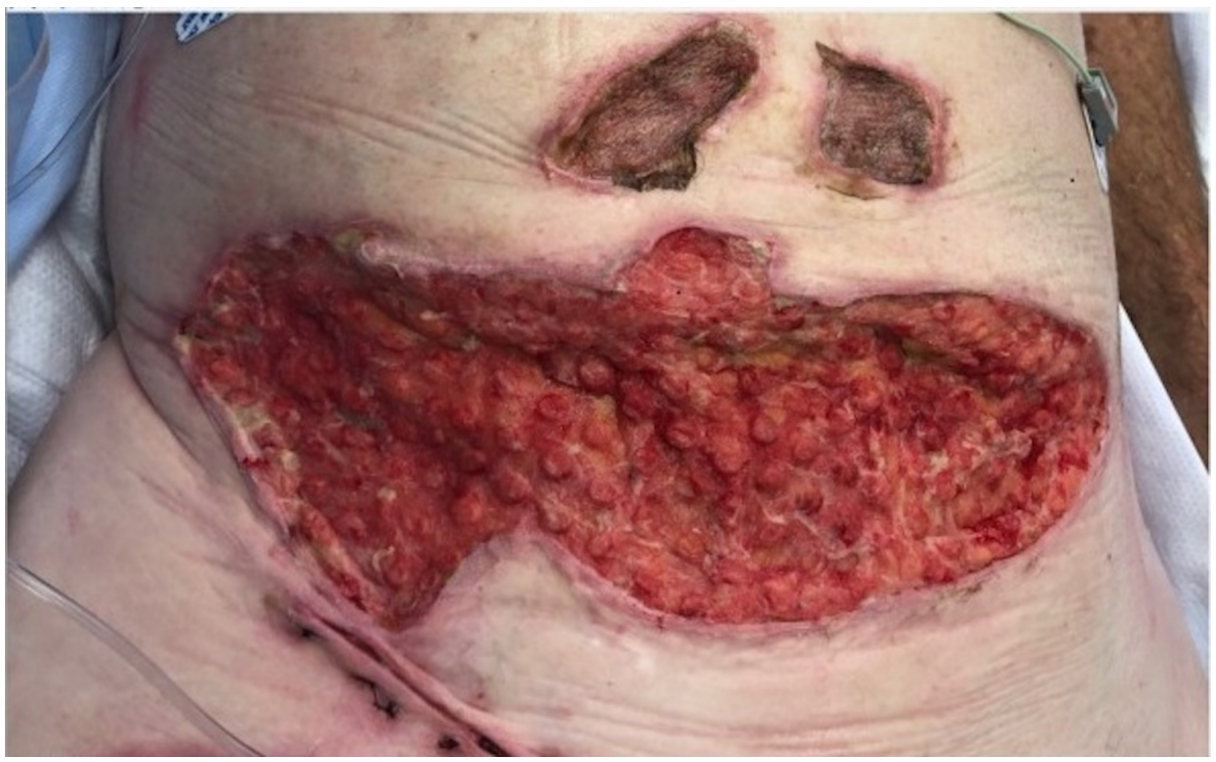

FIGURE 11: Followed by the appearance of the classic VVCC comedones granulation tissue

VVCC: V.A.C. VERAFLO CLEANSE CHOICETM

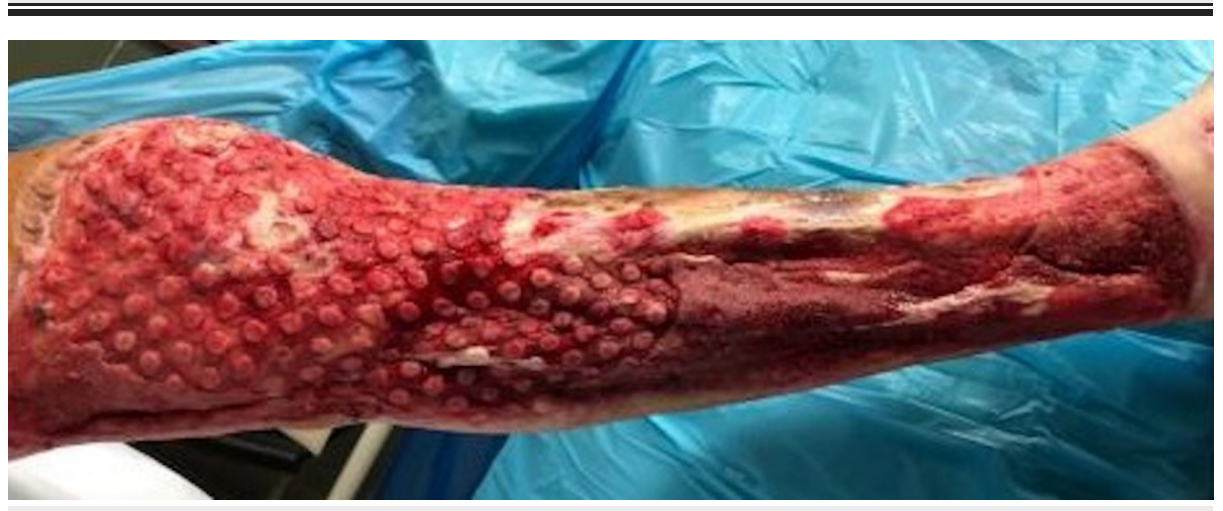

FIGURE 12: Followed by the appearance of the classic VVCC comedones granulation tissue after the multiple debridements and applications of the VVCC device

VVCC: V.A.C. VERAFLO CLEANSE CHOICETM 


\section{Cureus}

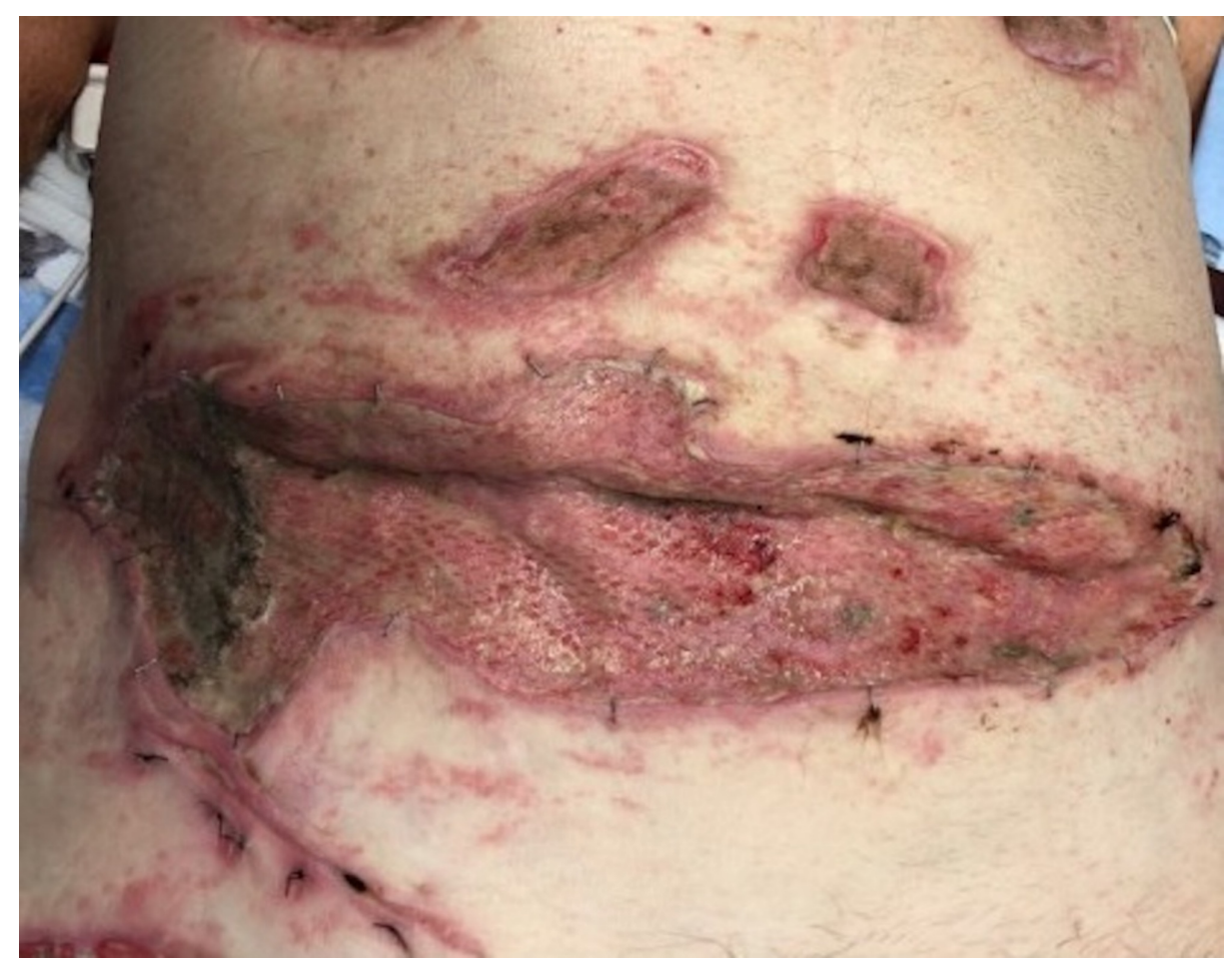

FIGURE 13: Finally, closure of the abdominal wound with split-thickness skin grafts

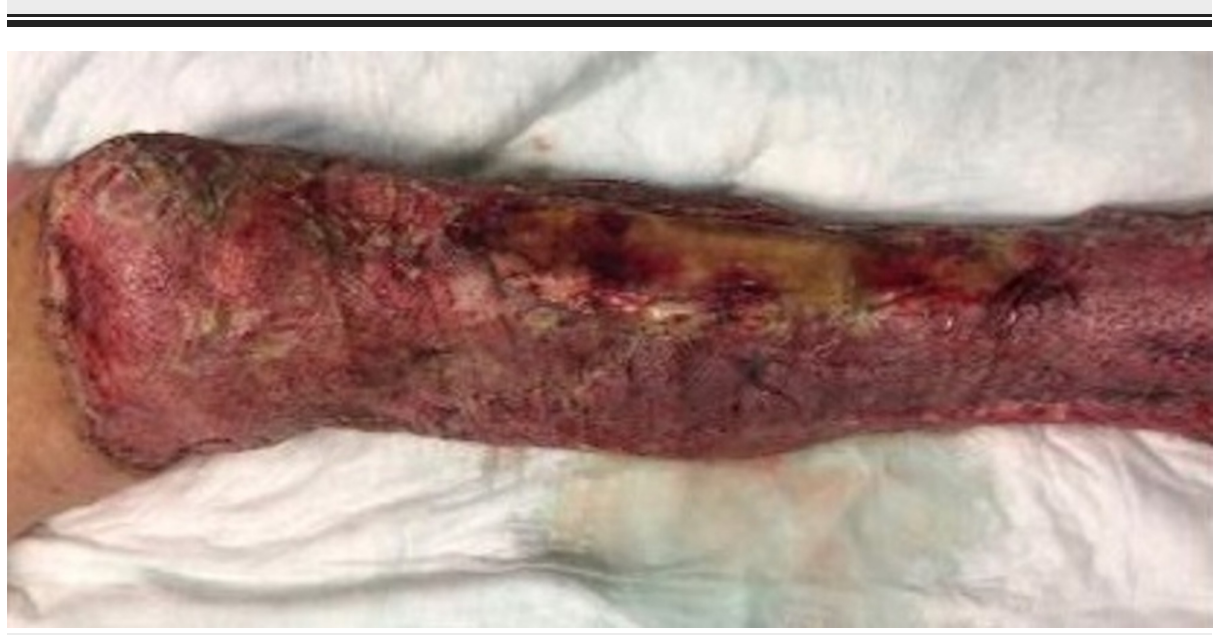

FIGURE 14: Subsequent closure of the left leg wound with splitthickness skin grafts

\section{Case 5: necrotizing fasciitis of the lower abdominal wall}

A 55-year-old female was admitted with a past medical history of multiple medical comorbidities, including diabetes mellitus (type 1), rheumatoid arthritis requiring immunosuppressant therapy, and baseline liver dysfunction. She had an abdominal wall necrotizing fasciitis due to an infected subcutaneous insulin pump. The patient underwent extensive debridement down to the rectus fascia and was left with a large soft tissue defect (Figure 15). The patient had placement of the VVCC NPET once the wound was debrided to viable tissue and the initial infection was controlled. The wound has been granulating and contracting with V.A.C. VERAFLO CLEANSE CHOICE ${ }^{\mathrm{TM}}$ also utilizing $\mathrm{HOCl}$ instillation of $30 \mathrm{ml}$ with a dwell time of 20 minutes every three hours and then returning to a negative pressure of $125 \mathrm{mmHg}$. Because of the patient's multiple medical issues and compromised immune system that would normally impair wound healing, the patient is weeks away from wound closure (Figure 16). The patient's therapy was completed with the closure of the wound following split-thickness skin grafting (Figure 17). 


\section{Cureus}

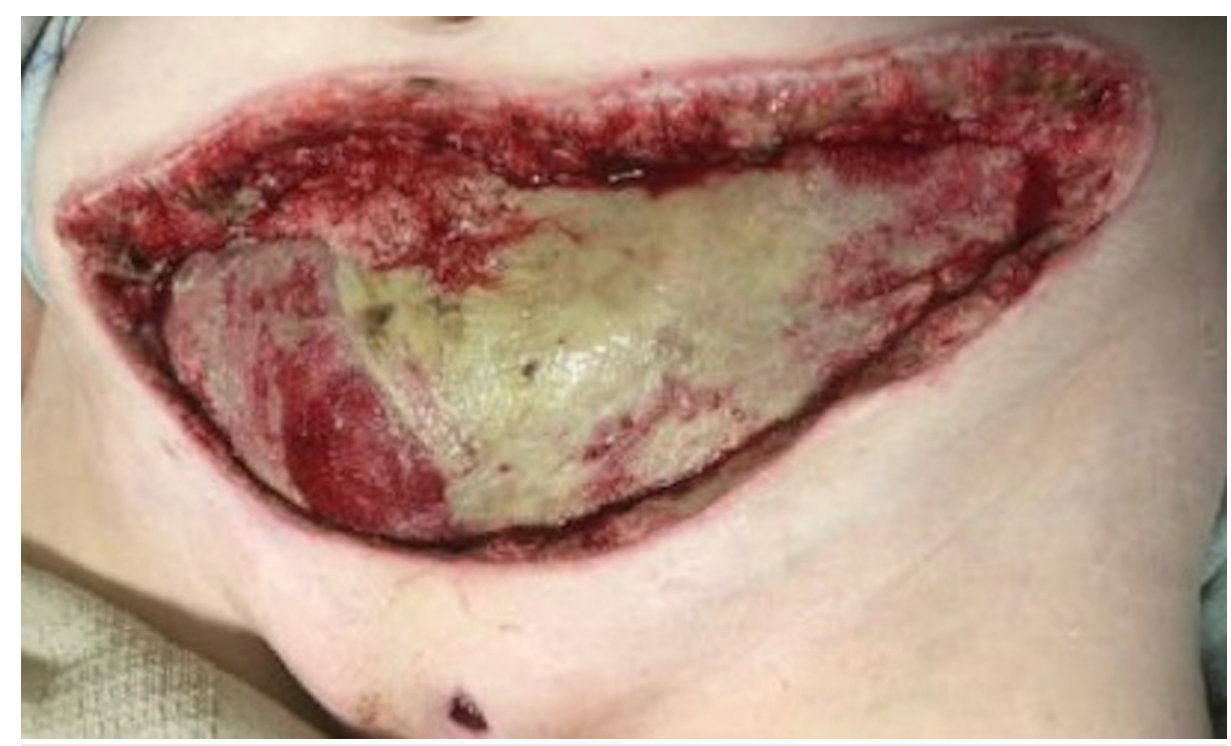

FIGURE 15: Large anterior abdominal wound after serial debridements

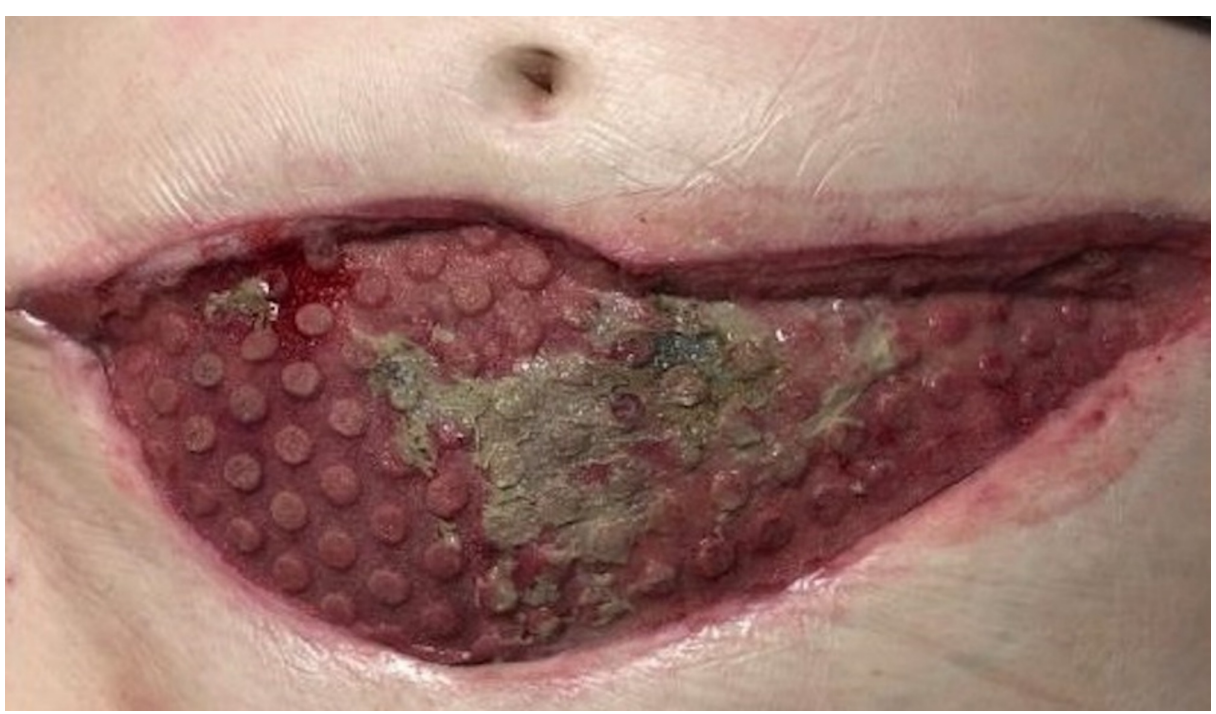

FIGURE 16: Contraction of the large anterior abdominal wound and development of comedone granulation tissue around a small area of remaining fibrinous exudate 


\section{Cureus}

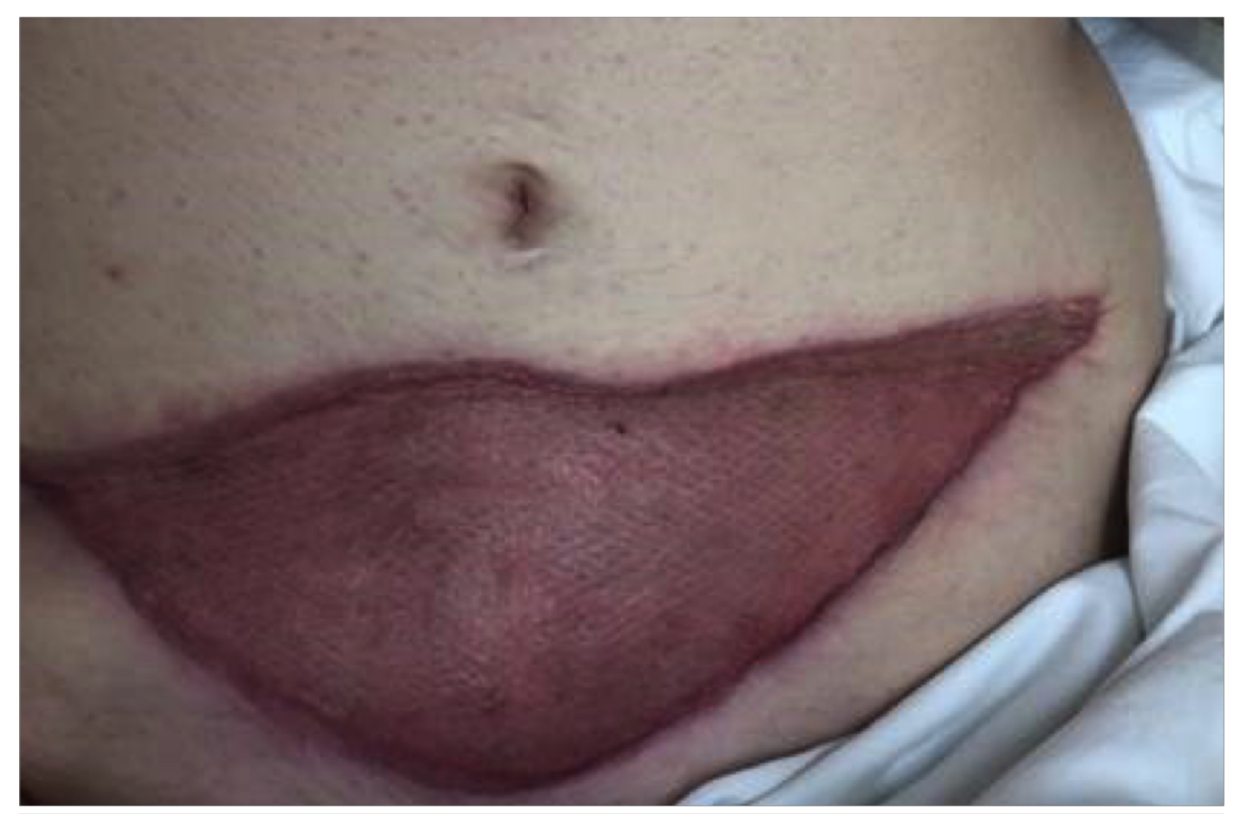

FIGURE 17: Lower abdomen following completion of therapy and skin grafting

\section{Discussion}

The use of the V.A.C. VERAFLO CLEANSE CHOICE ${ }^{\mathrm{TM}}$ (VVCC) has advanced our wound therapy regimen in the burn population and those with large wounds such as necrotizing fasciitis. Some burn center patients have large soft tissue defects following debridement that only require porcine xenografting or cadaveric allografting before they undergo split-thickness skin grafting while other patients have much deeper defects that require a healthy granulation bed before ultimately undergoing closure. The VVCC has provided an opportunity to effectively improve complex wound healing by the better elimination of the necrotic material and faster generation of granulation tissue in conjunction with the use of $\mathrm{HOCl}$ solution as reported by Fernandez and others [5-6]. Heibert and Robson described the reduction in bacterial growth with the use of $\mathrm{HOCl}$ acid compared to normal saline in the treatment of infected wounds [7]. In addition, it has been shown that the use of $\mathrm{HOCl}$ has led to a decrease in bacterial growth, and that even at low concentrations of HOCl, bacterial growth and cell division are decreased [8]. Studies in vitro have even shown that the presence of a prokaryotic biofilm is disrupted by at least $90 \%$ with just a brief exposure to $\mathrm{HOCl}$ [9]. When $\mathrm{HOCl}$ is used with an NPWT device, it has led to the more rapid development of granulation tissue and healthier wound beds [10]. Irrigation with HOCL should now be considered instrumental when the ROCF NPWT is used and irrigation is required to further treat the heavily exudative wounds or wounds that have heavy prokaryotic contamination before any attempt at closure. Other studies have also shown the benefit of HOCl solution using Vashe ${ }^{\circledR}$ wound therapy as the principal wound solution for dressings in non-healing and malodorous wounds [11-12].

\section{Conclusions}

While this is not the first description of the use of NPWT in the burn population, in our experience, the use of VVCC as an ROCF device with the use of HOCl irrigation results in a shorter time to wound closure using skin grafting techniques in the burn or necrotizing soft tissue infection patient populations.

\section{Additional Information}

\section{Disclosures}

Human subjects: Consent was obtained by all participants in this study. Conflicts of interest: In compliance with the ICMJE uniform disclosure form, all authors declare the following: Payment/services info: All authors have declared that no financial support was received from any organization for the submitted work. Financial relationships: All authors have declared that they have no financial relationships at present or within the previous three years with any organizations that might have an interest in the submitted work. Other relationships: Dr. Marc Matthews is a consultant for KCI Dr. Luis Fernandez is a speaker for KCI .

\section{References}

1. Harrington WZ, Strohschein BI, Reedy D, Harrington JE, Schiller WR: Pavement temperature and burns: 
streets of fire. Ann Emerg Med. 1995, 26:563-568. 10.1016/S0196-0644(95)70005-6

2. Saaiq M, ud Din H, Kan MI, Chaudhery SM: Vacuum-assisted closure therapy as a pretreatment for split thickness skin grafts. J Coll Physicians Surg Pakistan. 2010, 20:675-679.

3. Kim P, Attinger CE, Steinberg J, et al.: The impact of negative-pressure wound therapy with instillation compared with standard negative pressure wound therapy: a retrospective, historical, cohort, controlled study. Plast Reconstr Surg. 2014, 133:709-716. 10.1097/01.prs.0000438060.46290.7a

4. Teot L, Boissiere F, Fluieraru S: Novel foam dressing using negative pressure wound therapy with instillation to remove thick exudate. Int Wound J. 2017, 14:842-848. 10.1111/iwj.12719

5. Fernandez L, Ellman C, Jackson P: Initial experience using a novel reticulated open cell foam dressing with through holes during negative pressure wound therapy with instillation for management of pressure ulcers. J Trauma Treat. 2017, 6:410. 10.4172/2167-1222.1000410

6. Kim PJ, Applewhite A, Dardano AN, et al.: Use of a novel foam dressing with negative pressure wound therapy and instillation: recommendations and clinical experience. Wounds. 2018, 30:1-17.

7. Hiebert JM, Robson MC: The immediate and delayed post-debridement effects on tissue bacterial wound counts of hypochlorous acid versus saline irrigation in chronic wounds. E-Plasty. 2016, 16:261-268.

8. McKenna SM, Davies KJ: The inhibition of bacterial growth by hypochlorous acid. Possible role in the bacterial activity of phagocytes. Biochem. 1988, 254:685-692. 10.1042/bj2540685

9. Robson MC: Treating chronic wounds with hypochlorous acid disrupts biofilm . Today's Wound Clinic, United States; 2014.

10. Fernadez L, Ellman C, Jackson P: Initial experience using a novel reticulated open cell foam dressing with through holes during negative pressure wound therapy with instillation for management of pressure ulcers. J Trauma Treat. 2017, 6:410. 10.4172/2167-1222.1000410

11. Niezgoda JA, Sordi PJ, Hermans HE: Evaluation of Vashe wound therapy in the clinical management of patient with chronic wounds. Adv Skin Wound Care. 2010, 23:352-357. 10.1097/01.ASW.0000383198.35815.a2

12. Kantak NA, Misty R, Varon DE, Halvorson EG: Negative pressure wound therapy for burns . Clin Plastic Surg. 2017, 44:671-677. 10.1016/j.cps.2017.02.023 